\title{
Strategi Pelayanan Informasi untuk meningkatkan Keterbukaan Informasi Publik
}

\author{
Sintar Nababan \\ Manajemen Informasi dan Komunikasi (MIK), Sekolah Tinggi Multi Media Yogyakarta \\ Jl. Magelang KM 5,5 Yogyakarta, 55284, Indonesia \\ Corresponding author: sintarnababan@gmail.com
}

\begin{abstract}
The results of the Central Information Commission survey that the disclosure of public information from TVRI broadcasting institutions is very low when compared to other public bodies, such as State-Owned Enterprises (SOEs), Public Universities, and other institutions. This research aims to analyze the broadcasting agency's service strategy in improving public information disclosure and community participation. The method used is qualitative with data retrieval through interviews, observations, and documentation. The results showed that there are three broadcast service strategies used by Padang Public Broadcasting Agency, namely: 1) broadcasts must be neutral, not in favor of the interests of one particular party or group that is political, religious or class, information must be conveyed to all Indonesians in a balanced and objective manner; 2) it is not commercial, that broadcast programs can educate, provide quality entertainment as well as health information that corresponds to culture, local wisdom, and religion; 3) Independents do not depend on and are influenced by the government or certain groups in determining the pattern of broadcast events that characterize national values, pluralism and the value of local wisdom following the standards of broadcast programs. This research provides recommendations to LPP TVRI Padang to improve understanding of Law No.14/2008 by improving human resources competency to keep up with the development of communication information technology (ICT), and can immediately use applications that have been certainly by the Central Information Commission to be able to compete with other public institutions. Keywords: Central Information Commission; Public Broadcasting Agency (LPP); Service Strategy; TVRI
\end{abstract}

\begin{abstract}
Abstrak
Hasil survey Komisi Informasi Pusat bahwa keterbukaan informasi publik dari Lembaga penyiaran TVRI sangat rendah jika dibandingkan dengan badan publik lainnya, seperti Badan Usaha Milik Negara (BUMN), Perguruan Tinggi Negeri, dan lembaga lainnya. Penelitian ini bertujuan untuk menganalisis strategi pelayanan lembaga penyiaran dalam meningkatkan keterbukaan informasi publik dan partisipasi masyarakat. Metode yang digunakan adalah kualitatif dengan pengambilan data melalui wawancara, observasi, dan dokumentasi. Hasil penelitian menunjukkan ada tiga strategi pelayanan siaran yang digunakan Lembaga Penyiaran Publik Padang, yaitu: 1) siaran harus bersifat netral, tidak berpihak kepada kepentingan salah satu pihak atau kelompok tertentu yang bersifat politik, agama ataupun golongan, informasi harus disampaikan untuk seluruh masyarakat Indonesia secara berimbang dan objektif; 2) tidak komersial, bahwa program siaran dapat mendidik, memberi hiburan yang berkualitas serta informasi yang sehat yang sesuai dengan budaya, kearifan lokal dan agama; 3 ) independen tidak tergantung pada dan dipengaruhi oleh pemerintah atau golongan tertentu dalam menentukan pola acara siaran yang mencirikan nilai-nilai kebangsaan, pluralisme dan nilai kearifan lokal sesuai dengan standar program siaran. Penelitian ini memberikan rekomendasi kepada LPP TVRI Padang agar dapat meningkatkan pemahaman mengenai UU No.14 Tahun 2008 dengan peningkatkan kompetensi SDM agar dapat mengikuti perkembangan teknologi informasi komunikasi (TIK), dan dapat segera menggunakan aplikasi yang telah ditentukan oleh Komisi Informasi Pusat sehingga mampu bersaing dengan lembaga publik lainnya. Kata kunci: Komisi Informasi Pusat; Lembaga Penyiaran Publik (LPP); Strategi Pelayanan; TVRI
\end{abstract}

\section{Pendahuluan}

Lembaga Penyiaran Publik (LPP) merupakan lembaga independen yang dapat merepresikan kepentingan Publik dengan informasi siaran yang bermutu. Pengertian siaran bermutu adalah sajian programnya mencakup: liputan bencana yang humanis, liputan isu konflik yang berdasar pada peliputan dengan sensitif konflik, isu anak-anak dan program kriminal, isu budaya dan seni, isu terorisme, hak 
asasi manusia, kritis, dan independen terhadap pemerintah (Masduki \& Darmanto, 2015).

Mewujudkan hak informasi masyarakat, Lembaga Penyiaran publik berfungsi sebagai public broadcasting, public service, public broadcaster, public financing artinya semua dari, oleh dan untuk publik sehingga Lembaga penyiran Publik TVRI tidak berorientasi profit (not profit oriented) dimana siarannya dapat memberikan informasi yang sehat, edukatif, mencerdaskan serta memberikan pencerahan kepada masyarakat. Semakin banyak informasi dan siaran yang berkualitas disiarkan dan dapat memenuhi kebutuhan masyarakat dan menjadikan TVRI menjadi Lembaga publik yang dipercaya dan diminati penonton atau masyarakat.

Persaingan di dalam Industri Penyiaran dan regulasi media sangat erat kaitan dengan konten yang rendah, rating dan monopoli media serta politik ekonomi pemilik media, untuk menghadapi persaingan tersebut maka TVRI Padang perlu meningkatkan kreatifitas dan kualitas siaran agar siaran menarik dan ditonton pemirsa. Kesuksesan sebuah stasiun televisi diukur dari banyaknya penonton atau audience. Jumlah penonton berpengaruh kepada para pengiklan, semakin banyak penonton, iklan semakin mahal. Dana dari iklan memberikan pengaruh terhadap kelangsungan hidup suatu media, karena tayangan iklan dapat memberikan keuntungan secara finansial bagi media. Media penyiaran swasta umumnya tidak banyak menyiarkan acara bersifat pendidikan, namun lebih mengutamakan siaran yang bersifat hiburan, infotainment, film kekerasan, musik, dan lainnya yang menarik untuk ditonton. Hal inilah yang menyebabkan penyiaran swasta lebih diminati penonton dibandingkan penyiaran publik, meskipun banyak program siaran TV swasta yang melanggar etika penyiaran, aturan dan perundang-undangan siaran serta peraturan Komisi Penyiaran Informasi. Keterbukaan informasi diperlukan dalam penyiaran TV swasta, dengan melibatkan masyarakat secara aktif untuk menilai kinerjanya yang berkaitan dengan program produksi siaran, agar siaran lebih berkualitas dan mendidik.

Keterbukaan informasi publik masih sulit dilakukan karena pejabat badan publik beranggapan apabila melibatkan masyarakat dapat mempengaruhi penilaian buruk terhadap kinerja badan publik. Proses terwujudnya keterbukaan informasi publik cenderung dipengaruhi oleh seberapa besar kemauan dan komitmen dari pemegang otoritas dan penyedia informasi publik. Apakah secara politik pejabat publik membuka diri agar akses publik atas informasi dalam tata kelola urusan publik bisa dilangsungkan. Dalam mewujudkan penyelenggaraan pemerintahan yang transparan dan akuntabel, baik badan publik di tingkat pusat maupun daerah dituntut untuk berkomitmen tinggi dalam melaksanakan undang-undang untuk menciptakan praktik demokratisasi dan good governance (UU No.14 Tahun 2008).

Sutanto, Eko (2010) menyatakan bahwa upaya yang dapat dilakukan untuk mewujudkan keterbukaan informasi harus didukung oleh kemauan yang bersungguh-sungguh dari badan publik, tanpa khawatir terhadap dampak negatif terhadap keterbukaan. Perlu dipahami bahwa keterbukaan bukan tindakan yang mudah dijalankan, mengingat secara kultural budaya birokrasi yang berbelitbelit, kaku, kurang informatif, tertutup dan kurang ramah yang menjadikan suatu tren atau ciri dalam birokrasi pemerintahan.

Pelayanan publik adalah segala kegiatan pelayanan yang dilakukan oleh penyelenggara publik untuk upaya pemenuhan kebutuhan bagi penerima pelayanan maupun sebagai pelaksanaan untuk pemenuhan kebutuhan sesuai dengan peraturan perundang-undangan yang berlaku. Menurut Undang- Undang No. 25 tahun 2009 bahwa peningkatan Pelayanan publik melibatkan partisipasi masyarakat, terutama dalam proses penyelenggaraan Pelayanan yang meliputi: penyusunan kebijakan pelayanan publik, 
penyusunan standar pelayanan, pengawasan dan evaluasi penyelenggaraan pelayanan publik, dan pemberian penghargaan kepada badan publik dalam capaian kinerjanya ataupun meningkatkan partisipasi masyarakat dalam pelayanan publik untuk mengembangkan dan mendorong keterbukaan informasi bagi seluruh penyedia pelayanan publik di pusat maupun daerah.

Keterbukaan informasi tersebut mendorong masyarakat untuk berpartisipasi dalam meningkatkan kesejahteraan masyarakat dalam sosial dan budaya. Keterbukaan informasi publik bertujuan untuk memberikan jaminan hak bagi masyarakat untuk mengetahui kebijakan-kebijakan program dari pemerintah yang berkaitan dengan: 1) pengambilan keputusan menyangkut kepentingan publik; 2) mendorong partisipasi publik dalam proses pengambilan keputusan; 3) meningkatkan peran aktif masyarakat dalam pengambilan kebijakan dan pengelolaan badan publik secara baik; 4) mewujudkan penyelenggaraan pelayanan publik yang baik; dan 5) mengetahui alasan pengambilan kebijakan yang berpengaruh terhadap kehidupan masyarakat terutama untuk mendapatkan layanan informasi yang berkualitas yang digunakan untuk peningkatan dalam pengelolaan informasi (Tabel 1) (UU KIP, 2008).
Berbicaratentangketerbukaninformasihalini dapat menimbulkan kekhawatiran bagi lembaga publik karena dalam pemikirannya membuka berbagai kekurangan dan kelemahan berkaitan dengan berbagai tanggungjawabnya, sehingga dapat menimbulkan penilaian negatif dari publik. Perlu dipahami UU KIP ada pasal yang mengatur hak dan kewajiban publik dalam menyebarkan informasi, sebaliknya UU ini juga mengatur hak masyarakat untuk memperoleh informasi.

Lembaga penyiaran mempunyai peranan yang strategis dalam pembentukan proses demokrasi masyarakat dimana masyarakat sipil akan dapat memperluas ruang-sosial politiknya melalui dialog di ruang Publik. Lembaga Penyiaraan Publik (TVRI) Padang diharapkan mandiri dalam mengelola alur komunikasi dan pemerintah tidak membatasi pengelolaan siaran, serta memberikan ruang kepada publik untuk mengawasi kinerja operasional lembaga publik. Hal ini yang dimaksudkan adalah masyarakat bukan sebagai konsumen, tetapi sebagai warga yang peduli dan berpartisipasi dalam membangun lingkungan sosial politik. Partisipasi yang dapat dilakukan dengan memosisikan khalayak menjadi warga aktif dengan memberikan kepada masyarakat agar dapat memberikan masukan atau saran, serta

Tabel 1. Badan Publik wajib melaksanakan UU KIP

\begin{tabular}{lccc}
\hline \multicolumn{1}{c}{ Lembaga } & Jumlah & $\begin{array}{c}\text { Telah membentuk Pejabat } \\
\text { Pengelola Informasi Dan } \\
\text { Dokumentasi (PPID) }\end{array}$ & Persentasi \\
\hline Kesekretariatan Lembaga Negara & 7 & 5 & $71,5 \%$ \\
Kementerian & 34 & 15 & $44 \%$ \\
Lembaga Setingkat Menteri & 4 & 2 & $50 \%$ \\
LPNK & 28 & 16 & $21 \%$ \\
Lembaga Non Struktural & 88 & 4 & $4,5 \%$ \\
Lembaga Penyiaran Publik & 2 & - & $0 \%$ \\
Provinsi & 33 & 19 & $6 \%$ \\
Kabupaten & 398 & 3 & $4,5 \%$ \\
Kota & 93 & 56 & $3 \%$ \\
Jumlah & 687 & & $8 \%$ \\
\hline
\end{tabular}

Sumber: Kementerian PAN dan RB, (2011); Ditjen IKP Kementerian Kominfo (2011) 
berdiskusi untuk membentuk suatu konsensus atau keputusan untuk membangun solidaritas dalam informasi publik yang berkaitan dengan nilai-nilai kehidupan publik (Rohmad, 2014).

Lembaga Penyiaran Publik TVRI sebagai badan publik penyelenggara negara wajib melaksanakan undang-undang keterbukaan publik. Pengertian Badan Publik adalah lembaga Eksekutif, Judikatif, Legislatif, dan badan lainnya memiliki fungsi dan tugas pokok berkaitan dengan penyelenggaraan negara yang sebahagian atau seluruh dananya bersumber dari Anggaran Pendapatan dan Belanja Negara atau Anggaran Pendapatan dan Belanja Daerah bagi Badan Publik wajib melaksanakan pelayan Informasi Publik. Sumber pembiayaan Lembaga Penyiaran terdiri dari: iuran penyiaran, Anggaran Pendapatan Belanja Negara atau Anggaran Pendapatan Dan Belanja Daerah, Sumbangan Masyarakat, Siaran Iklan, dan Usaha lain yang sah yang terkait dengan Penyelenggaraan Penyiaran yang akan dikelola langsung secara transparan oleh Lembaga Penyiaran Publik sesuai dengan ketentuan peraturan perundang-undangan yang berlaku dan Peraturan Pemerintah Republik Indonesia No. 11 Tahun 2005, Pasal 14 Ayat 1 dan 2.
Peraturan ini menegaskan bahwa lembaga publik ini memberikan pelayanan informasi secara terbuka. Pelayanan publik merupakan hal yang sangat penting dalam upaya peningkatan kesejahteraan dan pembangunan kehidupan masyarakat menuju masyarakat informasi, akan tetapi masih banyak Badan publik belum melaksanakan UU NO 14 Tahun 2008. Dalam Undang-Undang tersebut diwajibkan setiap badan publik membentuk Pejabat Pengelola Informasi dan Dokumentasi (PPID).

Pelayanan publik yang baik atau pelayanan prima dilihat dengan sadanya transparansi, informasinya akurat, fleksibel, dan cepat. Pelayanan yang baik tersebutlah yang diinginkan oleh masyarakat. Dengan semakin terbukanya informasi dari suatu lembaga publik dapat meningkatkan pelayanan kepada masyarakat dan sekaligus masyarakat dapat menilai kinerja badan publik. Perbaikan pelayanan dapat dilakukan dengan berbagai cara atau strategi misalnya dengan menginformasikan, memberikan ide-ide baru, menambah pengetahuan baru dan memberikan solusi dalam penyelesaian masalah yang menyangkut program siaran yang dibutuhkan masyarakat.

Tabel 2. Badan Publik yang sudah melaksanakan UU KIP

\begin{tabular}{|c|c|c|c|c|c|c|}
\hline No & $\begin{array}{l}\text { Kualifikasi Badan } \\
\text { Publik }\end{array}$ & Informatif & $\begin{array}{l}\text { Menuju } \\
\text { Informatif }\end{array}$ & $\begin{array}{l}\text { Cukup } \\
\text { Informatif }\end{array}$ & $\begin{array}{l}\text { Kurang } \\
\text { Informatif }\end{array}$ & $\begin{array}{c}\text { Tidak } \\
\text { Informatif }\end{array}$ \\
\hline 1 & Perguruan Tinggi Negeri & $1 \mathrm{BP}$ & $7 \mathrm{BP}$ & $18 \mathrm{BP}$ & $15 \mathrm{BP}$ & $93 \mathrm{BP}$ \\
\hline 2 & $\begin{array}{l}\text { Badan Usaha Milik } \\
\text { Negara }\end{array}$ & $2 \mathrm{BP}$ & $2 \mathrm{BP}$ & $3 \mathrm{BP}$ & $9 \mathrm{BP}$ & $95 \mathrm{BP}$ \\
\hline $\begin{array}{l}3 \\
4\end{array}$ & $\begin{array}{l}\text { Lembaga Non Struktural } \\
\text { Lembaga Negara dan }\end{array}$ & $3 \mathrm{BP}$ & $2 \mathrm{BP}$ & $3 \mathrm{BP}$ & $4 \mathrm{BP}$ & $74 \mathrm{BP}$ \\
\hline & $\begin{array}{l}\text { Pemerintah Non } \\
\text { Kementerian }\end{array}$ & $3 \mathrm{BP}$ & $10 \mathrm{BP}$ & $6 \mathrm{BP}$ & $7 \mathrm{BP}$ & $19 \mathrm{BP}$ \\
\hline 5 & Pemerintahan Provinsi & $4 \mathrm{BP}$ & $5 \mathrm{BP}$ & $6 \mathrm{BP}$ & $6 \mathrm{BP}$ & $13 \mathrm{BP}$ \\
\hline 6 & Kementerian & $2 \mathrm{BP}$ & $10 \mathrm{BP}$ & $8 \mathrm{BP}$ & $6 \mathrm{BP}$ & $8 \mathrm{BP}$ \\
\hline 7 & Partai Politik & $0 \mathrm{BP}$ & $0 \mathrm{BP}$ & $9 \mathrm{BP}$ & $6 \mathrm{BP}$ & $1 \mathrm{BP}$ \\
\hline & Total $460 \mathrm{BP}$ & $15 \mathrm{BP}$ & $36 \mathrm{BP}$ & $53 \mathrm{BP}$ & $53 \mathrm{BP}$ & $303 \mathrm{BP}$ \\
\hline & Presentase & $3,26 \%$ & $7,83 \%$ & $11,52 \%$ & $11,52 \%$ & $65,87 \%$ \\
\hline
\end{tabular}

Sumber: Data hasil monitoring dan evaluasi keterbukaan Informasi KPI (2018) 
Berdasarkan data tabel 2, peneliti melakukan penelitian di Lembaga penyiaran TVRI Sumatera Barat sebagai televisi daerah yang menyiarkan informasi kepada publik. Program siarannya yang terdiri dari $90 \%$ acara siaran TVRI Nasional dan $10 \%$ siaran lokal. Siaran lokal menyajikan informasi mengenai budaya dan berbasis kearifan lokal. Menurut data Dirjen Keterbukaan Informasi Publik (Ditjen IKP Kominfo, 2011) dan Komisi Informasi Pusat Republik Indonesia (KIP Pusat, 2019) bahwa lembaga penyiaran TVRI dalam penerapan Undang-undang KIP No 14 Tahun 2008 masih rendah dibanding Lembaga Publik lainnya seperti BUMN, Perguruan Tinggi Negeri, Lembaga Pemerintah Non Kementerian dan Kementerian, dan lembaga lainnya.

Sesuai dengan Undang-Undang KIP No 14 Tahun 2008, badan publik wajib membentuk Pejabat Pengelola Informasi dan Dokumentasi (PPID), yang mengelola informasi menggunakan aplikasi terintegrasi, yaitu informasi setiap saat, informasi berkala, informasi serta merta dan informasi yang dikecualikan. Hingga saat ini, lembaga penyiaran publik TVRI belum mempunyai Pejabat Pengelola Informasi dan Dokumentasi (PPID), seluruh informasi publik, program siaran yang akan disiarkan atau dipublikasi, dikelola oleh bidang siaran dan produksi, baik yang menggunakan online dan teristerial.

StrategipelayananLembagaPenyiaranPublik dalam meningkatkan keterbukaan informasi publik dapat dilakukan dengan meningkatkan partisipasi masyarakat dalam ruang publik, pengelolaan dan pelayanan informasi, serta mengemplementasikan keterbukaan informasi publik sesuai dengan Undang-undang KIP No. 14 tahun 2008. Berdasarkan Undang Undang No 14 Tahun 2008 bahwa setiap lembaga publik wajib membuka informasi kepada masyarakat dan ada empat jenis informasi yang wajib diberikan badan publik kepada publik yaitu: (1) Informasi publik yang wajib disediakan dan diumumkan secara berkala, (2) Informasi publik yang wajib diumumkan secara serta merta, (3) Informasi publik yang wajib tersedia setiap saat, (4) Informasi yang dikecualikan. Berdasarkan hal tersebut maka tujuan penelitian ini untuk mengetahui strategi pelayanan Lembaga Penyiaran Publik TVRI Padang dalam meningkatkan Keterbukaan Informasi Publik.

Keterbukaan informasi dapat mendorong masyarakat berpartisipasi secara aktif dalam proses pengambilan keputusan untuk membuat kebijakan dalam pengelolaan badan publik yang baik. Dengan aktifnya masyarakat untuk memberikan informasi, ide-ide baru dan ikut serta mengevaluasi hasil kinerja lembaga penyiran hal ini dapat memperbaiki kinerja dan kualitas siaran sesuai dengan kebutuhan masyarakat. Selain itu keterbukan informasi dapat mendorong badan publik meningkatkan pelayanan kepada masyarakat, agar masyarakat mendapatkan informasi yang berkualitas.

Strategi dalam pelayanan informasi yang sesuai dengan Peraturan Pemerintah adalah bahwa siaran harus bersifat independent, netral, tidak komersil, juga siaran dapat sebagai perekat bangsa untuk kepentingan masyarakat diperlukan keterbukan informasi agar dapat mendorong badan publik dalam penyelenggaraan negara yang baik, transparan, efektif dan efisien serta akuntabel, sehingga lembaga penyiaran publik dapat menghasilkan layanannya informasi yang berkualitas. Informasi yang berkualitas dapat meningkatkan partisipasi aktif masyarakat, sehingga Lembaga publik dapat memberikan pelayanan yang baik kepada masyarakat agar meningkatkan kesejahteraa hidup masyarakat.

TVRI Padang memiliki visi dan misi bahwa orientasi kinerja lembaga penyiaran publik TVRI Padang memberikan pelayanan kepada publik untuk memenuhi kebutuhan, kepentingan masyarakat, sehingga agar siaran TVRI Padang perlu merencanakan strategi pelayanan dalam segala aspek di bidang penyiaran yang berkaitan dengan produk atau program siaran, pelaksanaan 
kegiatan atau kinerja karyawan, dan sikap perilaku (profesional) dalam melaksanakan layanan sesuai dengan peraturan pemerintah berkaitan dengan penyelenggaraan penyiaran. Masyarakat Minang yang sarat dengan nilainilai adat, budaya dan agama, mendorong TVRI Padang untuk melakukan inovasi baru guna meningkatkan program siaran lokal yang dapat dikemas menjadi suatu program tontonan yang menyentuh kebutuhan masyarakat, memberi pembelajaran nilai-nilai budaya setempat yang positif, dapat mempercepat akses masyarakat terhadap pendidikan dan budaya, mengembangkan ilmu pengetahuan, memperlancar interaksi masyarakat dengan cara melibatkan partisipasi masyarakat dalam perencanaan program siaran sebagai supervisi serta melakukan evaluasi terhadap kinerja Lembaga Penyiaran Publik. TVRI Padang telah berupaya meningkatkan keterbukan informasi publik dengan berpedoman pada undang-undang dan peraturan yang berlaku. Latarbelakang tersebut yang menjadikan penelitian ini bertujuan untuk menganalisis strategi pelayanan lembaga penyiaran dalam meningkatkan keterbukaan informasi publik dan partisipasi masyarakat.

\section{Metode Penelitian}

Penelitian ini dilaksanakan di Lembaga Penyiaran Publik TVRI Padang, Sumatera Barat. Metode penelitian yang digunakan adalah metode deskriptif kualitatif, dimana pengumpulan data dilakukan dengan tiga cara: (1) Wawancara mendalam (in dept-interview) yaitu wawancara berisi mengenai, pengalaman, pendapat, tanggapan, pengetahuan, dan fakta yang berkaitan dengan pelayanan informasi serta keterbukaan informasi yang sudah dilakukan; (2) Observasi, yaitu kegiatan mencari data untuk memberikan suatu kesimpulan atau diagnosis (Saputra, 2012:209). Observasi dilakukan pada aktifitas bidang program dan siaran terkait dengan aktifitas pelaksanaan kegiatan pelayanan informasi kepada publik atau produksi siaran dan sistem aplikasi keterbukaan informasi publik; (3) Dokumentasi, yaitu teknik yang digunakan untuk menelusuri data historis yang berkaitan dengan objek penelitian (Bungin, 2007:121) seperti dokumen berupa laporan tentang produksi siaran secara online ataupun streeming, arsip tentang kegiatan yang menggunakan produksi secara teristerial dan rekaman video yang berkaitan dengan kegiatan di bidang program siaran atau produksi siaran.

Penentuan narasumber dilakukan dengan menggunakan metode purposive sampling. Menurut Patton dalam Sutopo (2002 : 55), purposive sampling adalah peneliti menentukan kriteria yang diwawancarai dimana narasumber tersebut dianggap dapat memberikan dan mengetahui informasi serta terlibat secara langsung atau pun yang memahami masalahnya secara mendalam serta dapat dipercaya untuk menjadi sumber data yang sesuai dan benar.

Analisis data dilakukan menggunakan teknik analisis data Miles \&Huberman (dalam Emzir 2012:129) dengan melakukan reduksi data mengenai penelitian, penyajian data hasil reduksi disajikan dalam bentuk tabel dan dianalisis agar dapat ditarik kesimpulan dari penelitian ini.

\section{Hasil Penelitian dan Pembahasan Pelayanan Bersifat Netral}

Lembaga penyiaran publik yang berbentuk lembaga hukum yang didirikan oleh negara dan bersifat netral dalam pelayanan informasi yang dapat memberikan pendidikan, hiburan yang sehat, kontrol sosial dan perekat sosial serta melestarikan budaya bangsa demi kepentingan masyarakat di seluruh Indonesia. LPP TVRI stasiun Sumatera Barat (Padang) dapat menyiarkan siaran Lokal dan Regional dimana program acara terdiri hiburan, berita, pendidikan, informasi, budaya, life and culture, entertainment, sport, kids. Saat ini penyiaran TVRI Padang sudah mengunakan siaran digital melalui beberapa stasiun transmisi, karena LPP Sumatera barat mempunyai 14 
satuan transmisi, serta mengunakan siaran streaming melalui website www.tvrisumbar. co.id yang terintegrasi dengan Web TVRI pusat.

Pelayanan informasi LPP Sumatera Barat bersifat netral tidak berpihak kepada kepentingan salah satu pihak atau yang berbeda pendapat maupun kelompok tertentu yang bersifat politik, agama ataupun golongan. Sesuai dengan undang-undang keterbukaan informasi publik, ada empat informasi yang wajib diberikan badan publik kepada masyarakat seperti informasi berkala, informasi setiap saat, informasi serta merta dan informasi yang dikecualikan.

Informasi setiap saat dilaporkan kepada masyarakat secara online, dengan mengunakan Sistem Informasi Rencana Umum Pengadaan (SIRUP) yang terdiri dari dua jenis yaitu SIRUP Penyedia dan Swakelola. SIRUP Penyedia yaitu aplikasi melakukan kerjasama dengan pihak ketiga misalnya jika ada program kegiatan kurang lebih dari50juta rupiah, harus dikerjasama dengan pihak ketiga atau ada pihak ketiga yang ingin bekerja sama dengan TVRI akan diinformasikan melalui sistem ini sistem yang kedua adalah SIRUP Swakelola untuk menginformasikan kegiatan rutin yang berkaitan dengan program kerja, misalnya memproduksi siaran berita yaitu Berita: Ranah Minang; Siaran Pendidikan:
Nuansa Iman, Yang Muda Berprestasi, Siaran Hiburan: Bukan TalkShow Biasa, Dendang 15, Siaran Informasi: Perempuan, Pesona Sumbar, Dialog Khusus, Ruang Kesehatan dan Siaran Budaya: Arito Lapau, Randai. Informasi berkala ini diinformasikan untuk publik bagi siapa yang membutuhkan informasi tentang kegiatan program TVRI Padang dapat dilihat pada Sistem Swakelola. Sementara untuk kegiatan kerjasama MOU dengan Pihak Ketiga dapat dilihat pada sistem penyedia. Informasi untuk seluruh masyarakat khususnya masyarakat Padang. Untuk Informasi Setiap saat tentang sengketa informasi TVRI belum pernah meliput siaran ini untuk diinformasikan kepada masyarakat. Begitu juga dengan informasi yang dikecualikan mereka hanya menunggu informasi dari redaktur. Jika informasi dinggap tidak mendidik atau mencerdaskan, atau jika informasi tersebut dianggap dapat menggangu sistem keamanan negara, ketahanan ekonomi negara maupun hubungan internasional tidak akan disiarkan kepada publik.

Informasi serta merta biasanya disiarkan melalui media sosial, website. Jika peristiwa terjadi pada daerah yang sangat sulit dijangkau dengan peralatan teristerial akan menggunakan live phone dan live streaming misalnya siaran

Tabel 3. Observasi Siaran Netral

\begin{tabular}{|c|c|c|}
\hline Objek Observasi & Hasil & Keterangan \\
\hline Siaran Nasional dan Siaran & Disiarkan kepada seluruh & Program acara dapat menjadi \\
\hline Regional serta Siaran lokal & masyarakat Indonesia & kontrol sosial dan dapat \\
\hline & dengan merelay siaran & melecstarikan budaya bangsa \\
\hline & Nasional TVRI Pusat dan & untuk kepentingan \\
\hline & $\begin{array}{l}\text { menyiarkan siaran regional } \\
\text { ataupun lokal melalui studio }\end{array}$ & masyarakat Indonesia. \\
\hline & TVRI Padang. & \\
\hline Media penyiaran: Teristerial & disiarkan mengunakan & siaran disiarkan dengan \\
\hline dan On Line & jaringan satelit dan internet & $\begin{array}{l}\text { streaming, live, dan siaran } \\
\text { tunda atau recording. }\end{array}$ \\
\hline
\end{tabular}

Sumber: Hasil olah data observasi (2019) 
Tabel 4. Program Acara bersifat Netral yang disiarkan secara Teristerial

\begin{tabular}{|c|c|c|c|c|c|c|c|c|}
\hline No & Informasi & $\begin{array}{l}\text { Pendidikan/ } \\
\text { budaya }\end{array}$ & Hiburan & News & life and culture & Entertaiment & Sport & Siaran Pusat \\
\hline 1 & $\begin{array}{l}\text { Sumbar } \\
\text { Membangun }\end{array}$ & Perempuan & $\begin{array}{l}\text { Bukan Tolk } \\
\text { Show Biasa }\end{array}$ & $\begin{array}{l}\text { Suara Publik } \\
\text { Bicara }\end{array}$ & Pagi kita & Seni Tradisi & $\begin{array}{l}\text { Sport } \\
\text { SU }\end{array}$ & $\begin{array}{l}\text { Siaran Relay TVRI Nasional } \\
\text { dari pukul } 18.00-07.58 . \\
\text { Setiap hari. }\end{array}$ \\
\hline 2 & Salingka Tani & Kuliner & $\begin{array}{l}\text { Bukan Tolk } \\
\text { Show Biasa }\end{array}$ & $\begin{array}{l}\text { Film } \\
\text { Documnter }\end{array}$ & $\begin{array}{l}\text { Ayo Hidup } \\
\text { Sehat }\end{array}$ & Hiburan & & \\
\hline 3 & Dialog khusus & Ekspresi & Pagi Kita & $\begin{array}{l}\text { Sumatera } \\
\text { Barat Hari Ini }\end{array}$ & & & & \\
\hline 4 & $\begin{array}{l}\text { Polisi } \\
\text { Menyapa }\end{array}$ & Ayo Hidup Sehat & $\begin{array}{l}\text { Langgam } \\
\text { Melayu }\end{array}$ & Siaga Bencana & & & & \\
\hline 5 & siaga bencana & Nuansa Iman & $\begin{array}{l}\text { Melodi } \\
\text { Nostalgia }\end{array}$ & & & & & \\
\hline 7 & $\begin{array}{l}\text { Lensa } \\
\text { Olahraga }\end{array}$ & & & & & & & \\
\hline 8 & Salingka Tani & & & & & & & \\
\hline
\end{tabular}

Sumber: Diolah Peneliti. Pola Siaran LPP padang (2019)

bencana alam, kebaran hutan atau banjir. Dalam hal ini Lembaga Penyiaran Publik TVRI padang Untuk keterbukan informasi sudah melakukan secara netral, tanpa berpihak kepada seseorang yang berpengaruh atau kelompok tertentu, Siaran sesuai dengan prinsip jurnalisme dan etika yang berlaku dalam penyiaran.

Hasil wawancara dengan Kepala Seksi Bidang Program dan Pengembangan Usaha, Bapak Marjoni, menunjukkan bahwa Lembaga Penyiaran Publik TVRI Padang belum mempunyai sistem aplikasi yang terintegrasi sesuai dengan undang-undang Keterbukaan Informasi Publik akan tetapi TVRI Padang sudah mempunya aplikasi SIRUP (Sitems Informasi Rencana Umum Pengadaan) website, fortal dan media sosial.

Pada Tabel.3 dapat dilihat program acara yang bersifat netral dan wajib relay siaran TVRI Nasional. TVRI Padang dalam pelayanan informasi publik diproduksi dan disiarkan dengan sistem analog maupun digital secara reguler, lokal dengan standart siaran yang tinggi dan akan disiarkan ke seluruh masyarakat Indonesia tanpa diskriminasi.

\section{Pelayanan Siaran Tidak Komersil}

Sistem penyelengaraan penyiaran TVRI Padang berbasis publik, yang dikelelola badan publik, pada umunnya lembaga ini tidak komersil atau non profit (keuntungan) tujuan siaranya selalu berkaitan dengan peningkatan kesejahteraan sosial, peningkatan moral, kesehatan, pendidikan, pembentukan karakter, agama, dan lainnya. Bagi penyiaran swasta bahwa tingginya rating dari suatu program atau siaran akan menentukan lebih mudahnya mendapatkan iklan komersil, sementara untuk penyiaran publik TVRI Padang penayangan iklan lebih kepada iklan layanan masyarakat yang disiarkan secara memadai dan pada jam tayang utama.

Acara televisi saat ini banyak yang kurang tepat jam penayangannya, karena ditayangkan pada jam primetime dimana anak-anak di bawah umur ikut menonton tayangan yang kurang mendididk yang bahkan mengganggu jam belajar anak. Dampak dari siaran yang kurang baik tersebut dapat mengakibatkan perilaku agresif anak serta menjadikan anak anti terhadap lingkungannya. Hal tersebut nampak dengan banyaknya anak-anak atau pelajar dengan tingkat kecerdasan yang tinggi namun tidak beretika baik, seperti kasus pelajar SD yang melakukan kekerasan verbal maupun non verbal kepada temannya, atau para pelajar SMP dan SMA yang melakukan tawuran atau berkelahi antar sekolah atau antar kelompok.

Lembaga penyiaran publik bukan hanya berkembang di Indonesia saja, namun juga di negara Asia, Eropa, Amera dan negara lainnya. 
Untuk lembaga penyiaran publik di Amerika, memiliki perbedaan dengan lembaga penyiaran publik lainnya, karena pendiriannya bersifat tunggal dan tidak didirikan oleh negara atas nama publik tetapi atas nama komunitas, seperti Perguruan Tinggi, kelompok masyarakat, yang jumlahnya mencapai ratusan stasiun. Di kawasan Asia, model terbaik lembaga penyiaran publik adalah milik Jepang yang dikenal dengan NHK, dimana sumber pembiayaannya mengunakan iuran publik dan dibiayai negara.

TVRI Padang dalam upaya meningkatkan patisipasi masyarakat adalah dengan melibatkan tokoh agama, tokoh masyarakat dan para akademisi, bekerja sama membentuk forum diskusi ataupun rapat untuk membicarakan siaran atau program yang mendidik, memberi hiburan yang berkualitas serta informasi yang sehat yang sesuai dengan budaya, kearifan lokal dan agama. Masyarakat Sumatera Barat terdiri dari suku Padang, dengan sebagian besar menganut agama Islam dan beberapa agama lainnya, sehingga informasi berkala yang berkaitan dengan siaran, berita dan hiburan tidak komersil, akan disiarkan pada perayaan hari besar keagamaan, misalnya acara hari raya Idul fitri, acara Natal, dan acara keagamaans lainnya.

Untuk informasi serta merta seperti informasi mengenai kebakaran hutan, terjadinya konflik antar suku, menginformasikan mengenai wabah penyakit menular, atau informasi makananan yang mengandung racun, formalin kepada seluruh masyarakat Padang tanpa meminta imbalan, atau menginformasikan pesan dari seseorang yang memiliki kekuasaan atau berpengaruh dalam politik kepada publik, terjadinya kekeringan, kebakaran hutan, harus dapat dijelaskan sesuai fakta dilapangan tanpa menambahkan maupun mengurangi informasi yang sebenarnya. Hasil wawancara dengan Kepala Stasiun TVRI, Alri Pamuncak mengatakan bahwa: "Kebutuhan dan keinginan khalayak harus terpenuhi secara seimbang dengan demikian siaran yang berkualitas pasti disukai dan mendapat rating yang tinggi artinya bahwa lembaga publik menjadi media yang dipercaya dibanding media swasta karena informasi yang berkualitas, yang nantinya TVRI padang diharapkan menjadi pusat data penyiaran Indonesia" (24 Juli 2019)

Tabel 5. Program Tidak Komersil yang disiarkan secara teristerial

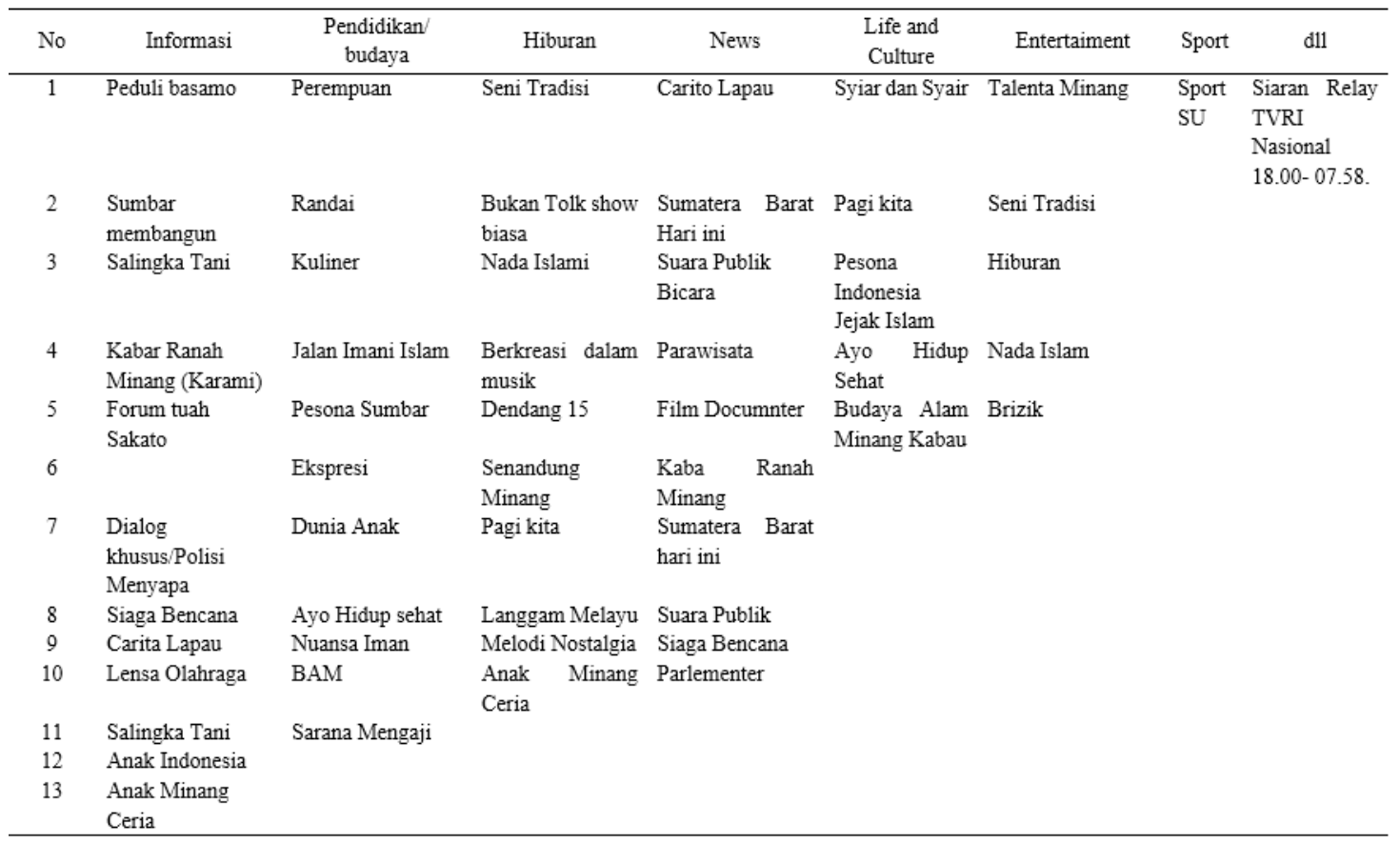

Sumber: Pola Siaran LPP Padang, diolah peneliti (2019) 
Untuk mengetahui informasi tentang masalah sosial, masalah bencana alam atau non alam dapat diakses melalui website: www tvrisumbar. id; instagram: @tvrisumbar dan media sosial face@tvrisumaterabarat._TVRI padang dalam liputan berita, siaran hiburan, siaran pendidikan, informasi maupun siaran budaya sudah berlandaskan etika dan prinsip jurnalistik.

Pada tabel 5 dapat dilihat bahwa program acara TVRI Padang meskipun dengan keterbtasan dana bersifat tidak komersil dimana isi siarannya atau konten lebih mengutamakan edukasi atau pendidikan bukan hanya hiburan semata, agar dapat menjaga mutu siaran dan menjadi lembaga penyiran publik yang tetap dicintai dan dipercaya publik untuk mempersatukan Negara Kesatuan Republik Indonesia.

\section{Pelayanan siaran Independent.}

Lembaga publik TVRI adalah lembaga publik yang independent tidak tergantung dan tidak dipengaruhi pihak lain, artinya tidak dapat diinterpensi oleh pemerintah atau kelompok manapun dalam pelayanan siaran baik informasi pendidikan, hiburan, informasi yang dapat menjadi perekat sosial dan menjaga citra positif bangsa di dunia internasional. Dalam penyebaran informasinya kepada publik, diawasi dan dikontrol oleh sebuah lembaga independen yang dikenal dengan nama Komisi Penyiaran Indonesia (KPI) sebagai perwakilan rakyat dalam mengawasi isi atau konten siaran.

Lembaga penyiaran publik juga ditujukan untuk mengimbangi dan mengurangi keabsolutan media swasta karena seringnya muncul dominasi kepemilikan media yang isi siarannya lebih mengutamakan kepentingan pemegang saham dan mengarah kepada bisnis maupun politik, dibandingkan kepentingan publik, sementara lembga penyiaran publik digunakan untuk kesehjahteraan rakyat. Pada umumnya kepemilikan media swasta adalah berbadan hukum dalam bentuk PT (persero) dan penyiaran publik berbadan hukum dalam bentuk Lembaga Penyiaran Publik (Darmanto, Masduki, 2016). Mengacu pada hal tersebut, seharusnya

Tabel 6. Hasil Observasi siaran Independen

\begin{tabular}{|c|c|c|}
\hline Objek Observasi & Hasil Observasi & Kesimpulan \\
\hline Siaran Independent & $\begin{array}{l}\text { Format acara dan pola acara } \\
\text { siaran ditentukan kepala } \\
\text { stasiun dan bidang program }\end{array}$ & $\begin{array}{l}\text { Tidak ada intervensi dari } \\
\text { pemerintah angota dewan, } \\
\text { kelompok politik tertentu. }\end{array}$ \\
\hline Sistem on Line & $\begin{array}{l}\text { Sistem Informasi rencana } \\
\text { Umum Pengadaan (SIRUP) } \\
\text { ada dua: Sirup Swakelola } \\
\text { untuk informasi program } \\
\text { kerja sedangkan Sirup } \\
\text { penyedia untuk informasi } \\
\text { kerjasama dengan pihak } \\
\text { kedua }\end{array}$ & $\begin{array}{l}\text { Informasi dibuka bagi umum } \\
\text { untuk menjalin kerjasama } \\
\text { dengan masyarakat. }\end{array}$ \\
\hline Call Phone & $\begin{array}{l}\text { Informasi Serta Merta yang } \\
\text { berkaitan dengan bencana } \\
\text { alam maupun yang non } \\
\text { Alam }\end{array}$ & $\begin{array}{lr}\text { Jika lokasi sulit dijangkau } \\
\text { masyarakat } & \text { dapat } \\
\text { diinformasikan } & \text { melalui } \\
\text { telepon } & \end{array}$ \\
\hline
\end{tabular}

Sumber: Hasil observasi diolah, (2019) 
media penyiaran dapat menjalankan fungsi pelayanan publiknya dengan baik, mendidik, informatif dan dapat menjadi kontrol sosial.

Menurut Undang-Undang penyiaran bahwa negara memberikan pelayanan yang sehat dengan prinsip dasarnya yaitu keberagaman isi (diversi of content) dan keberagaman kepemilikan (diversity of ownership). Lembaga penyiaran mempunyai peran yang penting dalam meningkatkan kehidupan sosial, budaya politik, dan ekonomi serta kebebasan dan memiliki tangung dalam menjalankan fungsinya. Sehubungan dengan hal itu, pemerintah memiliki tanggung jawab dalam aspek ekonomi dan industri, sementra KPI mengatur konten dan membuat pedoman perilaku penyiaran serta Standar Program Siaran (SPS).

Dalam regulasi penyiaran masih banyak ditemukan permasalahan yang menyangkut: konglomerasi media, konten yang rendah, dualisme regulator, priotitas rating, serta politik dan ekonomi pemilik media, yang kemudian dengan adanya revisi undang-undang penyiaran diharpkan adanya perbaikan regulasi mengenai permasalahan tersebut, sehingga publik kembali mendapatkan ranahnya. Hal tersebut menjadi tantangan bagi penyiaran publik dengan berbagai permasalahan dalam regulasi penyiaran, untuk tetap dapat mempertahankan kualitas informasi. Di harapkan lembaga penyiaran TVRI menjadi independen dan mampu menyajikan berita-berita yang lebih berimbang dan lengkap. Informasi publiksetiap saat, terutamamenyangkutinformasi keuangan, laporan kinerja karyawan, informasi yang berkaitan dengan masalah sosial dan konflik sosial yang terjadi di masyarakat sebaiknya disiarkan secara berimbang dan lengkap.

Dalam perencanaan Pola Program siaran TVRI padang memiliki hak penuh untuk menetukan siaran regional dan lokal. Siaran independent adalah siaran lokal.

Implementasi undang-undang Keterbukaan Informasi Publik (KIP) sampai sekarang belum mencapai target yang maksimal, hal ini disebabkan belum optimalnya sosialisasi kepada badan publik yang mengakibatkan masih rendahnya pemahaman terhadap keterbukaan informasi publik. Untuk saat ini, lembaga penyiaran publik yang belum mempunyai Pejabat Pengelola Informasi Daerah (PPID) mempunyai media online dan off line yang dikelola oleh Kasubseksi teknik produksi dan penyiaran sebagai pelayan informasi untuk meningkatkan keterbukaan informasi publik dengan memberikan pelayanan siaran yang berkualitas.

Persainganindustripertelevisiandalamnegeri semakin ketat, baik dalam segi bisnis maupun program. Kondisi ini turut membuat Lembaga Penyiaran Publik (LPP) Televisi Republik Indonesia (TVRI) semakin jauh tertinggal. Hal tersebut wajar terjadi, karena bisnis penyirn sangat bergantung dengan selera masyarakat. Di mana televisi swasta lebih mengarah untuk mencari rating, dan keuntungn, sementara lembaga penyiaran publik tidak bersifat komersil.

Penyiaran publik secara universal sebaiknya dapat memenuhi standar, dintaranya: mengusung pluralisme dan perbedaan (diversity) dalam siaran dan manajemen SDM; independent dalam pengambilan keputusan; menempatkan kualitas, bukan kuantitas kinerja, sebagai nilai ideal; serta membuka akses publik untuk mengontrol dan mengawasi melalui pelbagai instrumen kelembagaan, yang artinya bahwa penyiaran publik siarannya mencakup pluralisme karena masyarakat Indonesia terdiri dari berbagai suku dan budaya untuk menuju kesamaan hak, kesatuan serta kebhinekaan harus menjungjung tingi nilai-nilai pluralisme dan berani mengambil keputusan yang berkaitan dengan siaran yang mengedukasi bukan yang menghibur, siaran dilihat dari kualitas bukan dari kuantitas. Komisi Penyiaran Indonesia (KPI) dapat bersikap tegas terhadap televisi wasta, karena berbagai permasalahan mengenai isi siaran atau program televisi swasta seperti tayangan siaran yang tidak informatif, kurang akurat, tidak objektif, tidak berimbang, tendensius, dan kurang mendidik (tayangan bersifat kekerasan, dan 
Tabel 7. Siaran Independent Tahun 2019

\begin{tabular}{|c|c|c|c|c|c|c|c|}
\hline No & Informasi & $\begin{array}{l}\text { Pendidikan/ } \\
\text { budaya }\end{array}$ & Hiburan & News & Life and Culture & Entertaiment & Sport \\
\hline 1 & Peduli basamo & Perempuan & Seni Tradisi & Carito Lapau & Syiar dan Syair & $\begin{array}{l}\text { Talenta } \\
\text { Minang }\end{array}$ & Sport SU \\
\hline 2 & $\begin{array}{l}\text { Sumbar } \\
\text { membangun }\end{array}$ & Randai & $\begin{array}{l}\text { Bukan Tolk } \\
\text { Show Biasa }\end{array}$ & $\begin{array}{l}\text { Sumatera Barat } \\
\text { Hari ini }\end{array}$ & Pagi kita & Seni Tradisi & \\
\hline 3 & Salingka Tani & Kuliner & Nada Islami & $\begin{array}{l}\text { Suara Publik } \\
\text { Bicara }\end{array}$ & $\begin{array}{l}\text { Pesona } \\
\text { Indonesia } \\
\text { Jejak Islam }\end{array}$ & Hiburan & \\
\hline 4 & $\begin{array}{l}\text { Kabar Ranah } \\
\text { Minang } \\
\text { (Karami) }\end{array}$ & $\begin{array}{l}\text { Jalan Imani } \\
\text { Islam }\end{array}$ & $\begin{array}{l}\text { Berkreasi } \\
\text { dalam musik }\end{array}$ & Parawisata & $\begin{array}{l}\text { Ayo Hidup } \\
\text { sehat }\end{array}$ & Nada Islam & \\
\hline 5 & $\begin{array}{l}\text { Forum Tuah } \\
\text { Sakato }\end{array}$ & Pesona Sumbar & Dendang 15 & $\begin{array}{l}\text { Film } \\
\text { Documenter }\end{array}$ & $\begin{array}{l}\text { Budaya Alam } \\
\text { Minang Kabau }\end{array}$ & Brizik & \\
\hline 6 & Parlementaria & Ekspresi & $\begin{array}{l}\text { Senandung } \\
\text { Minang }\end{array}$ & $\begin{array}{l}\text { Kaba Ranah } \\
\text { Minang }\end{array}$ & & & \\
\hline 7 & $\begin{array}{l}\text { Dialog } \\
\text { khusus/Polisi } \\
\text { Menyapa }\end{array}$ & Dunia Anak & Pagi kita & $\begin{array}{l}\text { Sumatera Barat } \\
\text { hari ini }\end{array}$ & & & \\
\hline 8 & Siaga Bencana & $\begin{array}{l}\text { Ayo Hidup } \\
\text { sehat }\end{array}$ & $\begin{array}{l}\text { Langgam } \\
\text { Melayu }\end{array}$ & Suara Publik & & & \\
\hline 9 & Carita Lapau & Nuansa Iman & $\begin{array}{l}\text { Melodi } \\
\text { Nostalgia }\end{array}$ & Siaga Bencana & & & \\
\hline 10 & Lensa Olahraga & BAM & $\begin{array}{l}\text { Anak Minang } \\
\text { Ceria }\end{array}$ & Parlementer & & & \\
\hline 11 & Salingka Tani & $\begin{array}{l}\text { Sarana } \\
\text { Mengaji }\end{array}$ & & & & & \\
\hline $\begin{array}{l}12 \\
13\end{array}$ & $\begin{array}{l}\text { Anak Indonesia } \\
\text { Anak Minang } \\
\text { Ceria }\end{array}$ & & & & & & \\
\hline
\end{tabular}

Sumber: Pola Siaran LPP Padang, diolah peneliti, (2019)

siarannya didominasi oleh program infotainment dan sinetron yang mengutamakan sensasi yang didramatisasi dan kehidupan yang hedonisme atau hidup glamour). Untuk mendukung terwujudnya keterbukaan informasi sebaiknya Komisi Penyiaran membuat standar pelayanan informasi publik dan pedoman petunjuk teknis atau pelaksanaan, sesuai dengan penjabaran undang - undang KIP. Di dalam petunjuk teknis atau pelaksanaan perlu dibuat anggaran biaya, penyediaan sumber daya manusia. Dalam hal ini Komisi Informasi perlu melakukan kordinasi antara pusat dan provinsi sehingga informasi publik dapat diinformasikan dengan baik. Agar pelayanan publik berkualitas dapat dilakukan bukan hanya Juknis yang diperlukan tetapi diperlukan biaya operasinal dan juga sumber daya manusia serta sarana pendukung lainnya, seperti aplikasi yang terintegrasi berisi informasi berkala, informasi setiap saat, informasi serta merta, dan informasi dikecualikan. Lembaga Penyiaran Publik TVRI Padang sudah melaksanakan keterbukaan informasi publik dengan menyiarkan program siaran nasional, regional dan lokal.

Undang-undang Keterbukan Informasi Publik (KIP) sudah mengatur prosedural untuk mendapatkan informasi, jenis-jenis informasi yang wajib dikeluarkan badan publik, namun sampai sekarang penerapan keterbukaan informasi belum berjalan dengan baik. Dari beberapa hasil penelitian menyatakan bahwa masih rendahnya tingkat pelayanan informasi publik yang dilakukan oleh badan publik, seperti penelitian yang dilakukan oleh Rizki Eka Hidayah Yusuf, Endang Erawan dan Hairunnisa (2018), bahwa di Kalimantan Timur belum semua masyarakat mengetahui adanya Undang-undang keterbukaan informasi publik sehingga masyarakat tidak mengetahui hak dan kewajibannya terhadap informasi publik, hal ini menunjukkkan bahwa pelayanan Badan Publik terhadap informasi publik masih sangat rendah. Begitu juga hasil penelitian yang dilakukan Agus Setiaman, Dadang 
Sugiana, Jimi Narotama Mahameruaji (2013) di Pemerintahan Kota (PEMKOT) Bandung menunjukkan bahwa kurangnya sosialisasi tentang implikasi undang-undang keterbukaan informasi publik. Penelitian yang dilakukan Sintar, Nababan (2018) di Pemerintahan Daerah Tapanuli Utara menunjukkan bahwa Pemda Taput belum maksimal memberikan pelayanan Informasi kepada masyarakat karena Sistem Aplikasi Keterbukaan Informasi belum terintegrasi sesuai dengan UU No 14.

Berdasarkan hasildari penelitian terdahulu, menunjukkan bahwa pemerintah yang diwakili Badan Komisi Nasional Pusat ataupun Daerah masih belum efektif untuk mensosialisasikan kepada masyarakat untuk mendapatkan informasi yang benar dan sehat serta mengedukasi bahwa negara memberikan jaminan bagi masyarakat untuk mendapatkan kebebasan informasi yang berkaitan agama, budaya adat istiadat dan nilai-nilai kehidupan yang dapat meningkatkan kesejahteraan bagi masyarakat.

Perkembangan teknologi media atau cyber media sangat berpengaruh terhadap pembentukan khalayak atau pemirsa. Khalayak di media cyber memiliki karakteristik yang berbeda dengan media massa arus utama (mainstream) baik secara teori maupun praktik. Era digital memunculkan media baru seperti media sosial, whatsApp, facebook, yang menonjolkan kecepatan, sementara media mainstream lebih menonjolkan keakurasian informasi. Dengan era baru sekarang khalayak tidak sekedar menjadi objek sasaran dari pesan tetapi khalayak sudah jauh lebih interkatif terhadap pesan atau informasi.

Lembaga Penyiaran Publik memerlukan suatu strategi pelayanan informasi kepada masyarakat, untuk dapat meningkatkan pengetahuan, kecerdasan serta partisipasi masyarakat dalam pembangunan, ekonomi, sosial atau kesejahteraan masyarakat sesuai dengan peraturan Pemerintah Republik Indonesia No 13 Tahun 2000. Lembaga penyiaran publik yang menyelenggarakan kegiatan penyiaran televisi, bersifat independen, netral dan tidak komersil yang dapat memberikan pelayanan yang berkualitas untuk kepentingan masyarakat.

Peneliti menemukan ada tiga strategi untuk penyelenggaran keterbukaan informasi yaitu: (1) siaran bersifat netral atau isi siaran tidak berpihak kepada kepentingan salah satu pihak atau yang berbeda pendapat maupun kelompok tertentu yang bersifat politik, agama ataupun golongan, wajib disiarkan bagi seluruh masyarakat Indonesia dan tidak komersil; (2) siarannya selalu berkaitan dengan peningkatan kesejahteraan sosial, peningkatan moral, kesehatan, pendidikan, pembentukan karakter, agama bukan hanya enak ditonton serta independent; (3) pelayanan siaran tidak tergantung tidak dipengaruhi pihak lain, artinya tidak dapat diinterpensi oleh pemerintah atau kelompok manapun dimana isi siaran yang berkaitan informasi pendidikan, hiburan yang sehat, informasi budaya yang dapat menjadi perekat sosial. Informasi ini sudah dipublikasi kepada seluruh masyarakat melalui media online ataupun teristerial.

\section{Simpulan}

Pelayanan informasi bahwa LPP TVRI Padang, Sumatera Barat sudah memperlihatkan sifat netral tidak berpihak kepada kepentingan salah satu pihak atau yang berbeda pendapat maupun kelompok tertentu yang bersifat politik, agama ataupun golongan maupun pemerintah. Sifat netral tersebut belum terlihat untuk informasi berkala penyiaran TVRI Padang yang terlihat dengan belum adanya laporan keuangan belum dilaporkan kepada masyarakat baik secara manual maupun menggunakan sistem aplikasi, namun laporan hanya disampaikan langsung kepada TVRI pusat secara manual. Keterbukan informasi publik tersebut meningkatkan partisipasi masyarakat dengan adanya keterlibatan tokoh agama, tokoh masyarakat dan para akademisi, yang bekerjasama membentuk forum diskusi ataupun rapat untuk membicarakan isi siaran 
atau program yang mendidik, memberi hiburan yang berkualitas serta informasi sehat yang sesuai dengan budaya, agama dan kearifan lokal.

Sistem penyelengaraan penyiaran TVRI Padang berbasis publik, yang dikelelola badan publik, dimana lembaga ini tidak komersil atau non profit (keuntungan), menunjukkan masyarakat Padang yang kurang berminat menonton siaran TVRI Padang, karena kemasan program kurang menarik dan menghibur jika dibandingkan dengan program acara media swasta, akibatdariketerbatasananggaran produksi serta kemampuan SDM untuk mengimbangi perkembangan teknologi komunikasi.

Lembaga publik TVRI Padang adalah lembagapublikindependentyang tidaktergantung dan tidak dipengaruhi oleh siapapun termasuk pemerintah atau golongan untuk memberikan pelayanan informasi publik baik informasi pendidikan, hiburan, bahkan informasi anggaran atau keuangan serta laporan kinerja pegawai. Untuk mewujudkan keterbukan informasi ke publik lembaga penyiaran TVRI Padang tidak hanya mendapat pengawasan oleh KPI namun juga oleh masyarakat. Belum maksimalnya pelayanan informasi publik yang dilakukan TVRI Padang disebabkan masih kurangnya pemahaman para pengambil keputusan tentang Undang-Undang Keterbukaan Informasi Publik. Pemikiran para pengambil keputusan jika anggaran diinformasikan ke publik menimbulkan masalah baru apabila ada pemahaman yang berbeda terhadap informasi tersebut. penyiaran Publik TVRI Padang, di dalam program siarannya sudah dapat menunjukkan sifat netral, tidak komersil dan independent untuk menentukan pola siaran. Untuk pola siaran yang mengacu pada ketiga strategi yang telah dipaparkan sebelumnya, bahwa informasi yang disiarkan oleh lembaga penyiaran publik ini sudah sangat sesuai dengan UndangUndang No. 14 tahun 2008, dalam hal ini Lembaga Penyiaran Publik TVRI Padang sudah memberikan pelayanan publik secara terbuka meskipun belum mengunakan aplikasi yang telah ditentukan oleh Komisi Informasi Pusat, sehingga hasil survei yang dilakukan KIP mengatakan bahwa lembaga penyiaran publik TVRI pusat ataupun daerah belum informatif dibandingkan dengan lembaga publik lainnya.

\section{Daftar Pustaka}

Bungin, Burhan. (2007). Penelitian Kualitatif. Surabaya: Kencana.

Ditjen KIP. Kemenkominfo.(2011). Laporan Layanan Informasi Publik. Jakarta: Ditjen Keterbukaan Informasi Publik Kemenkominfo.

Emzir. (2012). Metodologi Kualitatif Analisi Data. Jakarta:PT Grafindo Persada.

KPI. (2018). Hasil survey Indeks Kualitas Program Siaran Televisi. Jakarta: Komisi Penyiaran pusat.

Masduki, Darmanto. (2015). Save RRI-TVRI Dokumen Inisiatif Publik untuk transformasi Lembaga Penyiaran Publik di Indonesia, Yogyakarta: RP LPP dan Yayasan Tifa.

Masduki, Darmanto. (2006). Lembaga Penyiaran Publik (Tata Kelola dan Kepemilikan), Yogyakarta: LPP dan Yayasan Tifa.

Nababan, Sintar. (2018). Strategi Pelayanan Prima. Yogyakarta: STMM.

Peraturan Pemerintah Republik Indonesia No. 11 tahun 2005. Penyelenggaraan Penyiaran Lembaga Penyiaran Publik. Jakarta: Kemkominfo.

Rohmad, Efendi. (2014). Memperluas Partisipasi Demokratis Masyarakat Dalam Lembaga Penyiaran Radio Televisi Republik (LPP RTRI) Malang: Universitas Merdeka Malang.

Saputra, Uhar. (2012). Metode Penelitian: Kualitatif, Kuantitatif dan Tindakan. Jakarta: PT. Raja Grafindo persada.

Sari, Wina Puspita., Nursyamsih, Indah. (2013). Strategi Humas dalam memperbaiki Citra TVRI di Mata Publik. Jurnal Komunikasi, 1(1), 1-19. $\quad$ https://doi.org/10.21009/ 
communicology.011.04

Setiaman, Agus, Sugina, Dadang., dan Mahameruaji,Jimi Narotam. (2013). Implementasi Kebijakan Keterbukaan Informasi. Jurnal Kajian Komunikasi, 1(2). 196-205. $\quad$ https://doi.org/10.24198/jkk. v1i2.6044

Sutanto, Eko. (2010). Teknik Komunikasi Efektif: Strategi Dalam Keanekaragaman Masyarakat, Jakarta: Tarumanegara.

Sutopo, H.B. (2006). Metodologi Penelitian Kualitatif: Dasar Teori dan praktek. Surakarta: Universitas Sebelas Maret Press. Undang-Undang Republik Indonesia No. 14 Tahun 2008. Tentang Keterbukaan Informasi
Publik. Jakarta: Departemen Komunikasi dan Informatika Republik Indonesia.

Wakidor kohar. (2017). TVRI Sumbar dan Representasi budaya lokal, Post Diskominfo: Sumatera Barat.

Yusuf, Rizki Eka Hidayah., Erawan, Endang, dan Hairunnisa. (2018). Analisis Strategi Komunikasi Komisi Informasi Dalam Mensosialisasikan Undang-Undang Nomor 14 Tahun 2008 Tentang Keterbukaan Informasi Publik Di Kalimantan Timur. eJournal Ilmu Komunikasi, 6(3), 29-43. Retrived from https://ejournal.ilkom.fisipunmul.ac.id/site/?p=3440 